М. Е. Килуновская, Вл. А. Семенов, В. С. Бусова, Х. Х. Мустафин, И. Э. Альборова, Н. Н. Потрахов, Н. Е. Староверов, М. Б. Медникова МУМИФИЦИРОВАННОЕ ПОГРЕБЕНИЕ РЕБЕНКА ИЗ МОГИЛЬНИКА САРЫГ-БУЛУН (ЦЕНТРАЛЬНАЯ ТУВА) В СВЕТЕ ДАННЫХ АРХЕОЛОГИИ, РЕНТГЕНОГРАФИИ, АНТРОПОЛОГИИ И ГЕНЕТИКИ*

doi: 10.30759/1728-9718-2021-4(73)-6-18

УдК 903.5(571.52)“638”

ББК 63.442.7(253.5)

В 1988 г. на правом берегу Енисея в Центральной Туве были исследованы курганы 1 и 2 могильника Сарыг-Булун, содержавшие семь погребений. Погребение 5 привлекло особое внимание: в нем были обнаружены частично мумифицированные останки ребенка в деревянной колоде с необычным инвентарем (лук, колчан со стрелами, шапочка, чекан на деревянной рукояти). В статье представлены результаты экспертизы мумии девочки методом микрофокусной цифровой рентгенографии и нового палеогенетического исследования, позволившего определить митохондриальную гаплогруппу ребенка - D4g2, распространенную в Восточной и Центральной Азии. Погребальный инвентарь говорит о высоком статусе погребенной. Определен ее биологический возраст - 6-7 лет. Выявлены индикаторы физиологического стресса (линии Гарриса), наличие при жизни ребенка заметных физических нагрузок на пояс верхних конечностей, перенесенный рахит. Рентгенография позволила обнаружить не видимые при поверхностном осмотре артефакты, например не замеченный ранее в колоде нож. Данные генетики согласуются с наблюдениями о возможной горизонтальной уплощенности лицевого скелета девочки и лопатообразной форме ее верхнего резца. Примененные методы и полученные результаты позволяют в новом свете взглянуть на вопросы генезиса алды-бельской культуры и тему детства в раннескифское время.

Ключевые слова: ранний железный век, Тува, мумия, микрофокусная рентгенография, биоархеология детства, палеопатология, палеогенетика, мтДНК, таргетное секвенирование

Килуновская Марина Евгенъевна - к.и.н., с.н.с. Отдела археологии Центральной Азии и Кавказа, Институт истории материальной культуры РАН (г. СанктПетербург)

E-mail: kilunmar@mail.ru

Семенов Владимир Анатольевич - к.и.н., с.н.с. Отдела археологии Центральной Азии и Кавказа, Институт истории материальной культуры РАН (г. СанктПетербург)

E-mail: ranbov@yandex.ru

Бусова Варвара Сергеевна - м.н.с. Отдела археологии Центральной Азии и Кавказа, Институт истории материальной культуры РАН (г. Санкт-Петербург) E-mail: kulturnijkarman@gmail.com

Мустафин Харис Харрасович - к.т.н., заведующий лабораторией исторической генетики, радиоуглеродного анализа и прикладной физики, Московский физико-технический институт (г. Москва)

E-mail:kh-mstf@yandex.ru

* Исследование проведено в рамках программы фундаментальных научных исследований Государственных академий наук по теме государственной работы № o1842019-ооо4 «Взаимодействие древних культур Северной Евразии и цивилизаций Востока в эпоху палеометалла
Альборова Ирина Эдуардовна - к.б.н., с.н.с. лаборатории исторической генетики, радиоуглеродного анализа и прикладной физики, Московский физикотехнический институт (г. Москва)

E-mail:ira_teuchezh@mail.ru

Потрахов Николай Николаевич - д.т.н., професcop, заведующий кафедрой электронных приборов и устройств, Санкт-Петербургский государственный электротехнический университет (г. Санкт-Петербург) E-mail:nn@eltech-med.com

Староверов Николай Евгенъевич - ассистент кафедры электронных приборов и устройств, Санкт-Петербургский государственный электротехнический университет (г. Санкт-Петербург)

E-mail: niko205st@mail.ru

Медникова Мария Борисовна - д.и.н., в.н.с. отдела теории и методики, Институт археологии РАН (г. Москва)

E-mail:medma_pa@mail.ru

(IV тыс. до н. э. - I тыс. до н. э.)» и в рамках госзадания № AAAA-A18-118011790о92-5 («Археологические и антропологические источники и верификация гипотез: методические аспекты фундаментального знания и полевых исследований») 


\section{Археологический контекст}

Одной из важнейших проблем в истории Северной Евразии является изучение памятников раннескифского времени. Вопрос о происхождении и ранней истории племен скифского облика до сих пор остается открытым. $\mathrm{C}$ этой точки зрения комплексное изучение непотревоженного и хорошо сохранившегося погребения ребенка на могильнике Сарыг-Булун (правый берег Енисея недалеко от поселка Баян-Кол) имеет большое значение.

Раннескифское время (VIII-VI вв. до н. э.) в Туве представлено памятниками алдыбельской культуры (выделена А.Д. Грачом ${ }^{1}$ и делится на несколько этапов), ${ }^{2}$ с особыми погребальными сооружениями - курганамикладбищами одной семьи (под одной каменной насыпью, окруженной кольцом из крупных камней). Детские захоронения иногда располагаются за пределами крепиды. Для алды-бельских памятников характерны определенные типы наконечников стрел, втульчатые боевые чеканы, пекторали, серьги с конусом, бронзовые зеркала с бортиком и гладкие с центральной ручкой и др.

Погребения под насыпями курганов могильника Сарыг-Булун, а также инвентарь этих погребений подробно описаны ранее. ${ }^{3}$ Bce находки имеют аналогии в памятниках алды-бельской культуры, прежде всего в погребально-поминальных комплексах Аржан-2 и Чинге-Тей I.

Погребение 5 (рис. 1) под насыпью кургана 2 к северо-востоку от центральной могилы 4 представляло собой захоронение в лиственничной колоде, опущенной в овальную яму глубиной о,6 м, перекрытую несколькими слоями плит, а также деревянной крышкой. Изза образовавшейся герметичности произошла естественная частичная мумификация тела и хорошо сохранились многие органические материалы. Одежда представляла собой шубу, сшитую из шкурок грызунов, прослежены следы нижней юбки из шерстяной ткани.

\footnotetext{
${ }^{1}$ См.: Грач А. Д. Новые данные по древней истории Тувы // Уч. зап. ТНИИЯЛИ. 1971. Вып. 15. С. 96, 97.

${ }^{2}$ См.: Савинов Д. Г. Ранние кочевники Верхнего Енисея. Археологические культуры и культурогенез. СПб., 2002. C. $97-101$.

3 См.: Семенов Вл. А., Килуновская М. Е. Новые памятники раннего железного века в Туве // Информационный бюллетень МАИКЦА. М., 1990. Вып. 17. С. 36-47; Уникальное захоронение ребенка раннескифского времени на могильнике Сарыг-Булун (Тува) / Килуновская М. Е. [и др.] // Stratum Plus. Археология и культурная антропология. 2020. № 3 . C. $380-387$.
}

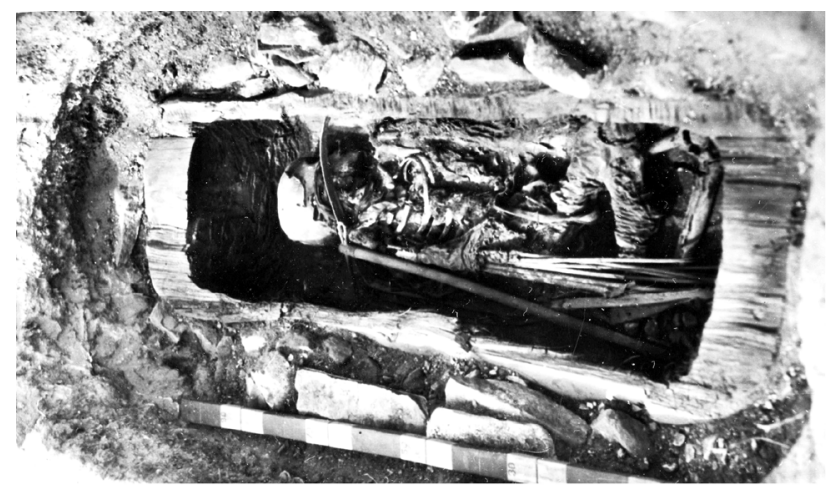

1

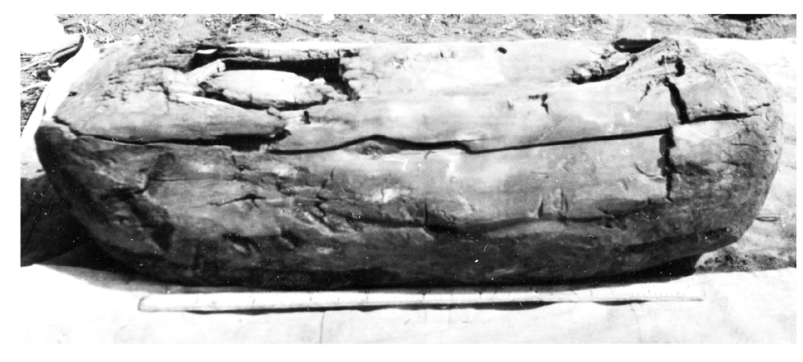

2

Рис. 1. Могильник Сарыг-Булун, могила 5.

Фото захоронения ребенка в колоде в момент обнаружения (1) и колоды (2) 1988 г.

За спиной девочки был уложен набор оружия, характерный исключительно для мужских раннескифских комплексов - лук, колчан со стрелами и чекан. Уникально и то, что сохранились все деревянные части оружия. Лук из Сарыг-Булуна - это первая находка целого лука скифского времени в Туве (рис. 2). Он относится к разряду простых - сделан из цельного куска березы, в сечении имеет сегментовидную форму. Его общая длина 100 cм, ширина 4 см; на концах имеются вырезы для крепления тетивы. По-видимому, лук был обклеен слоем вываренной коры, внешне очень похожей на бересту с кибити лука из кургана 1 на могильнике Олон-Курин-Гол-10 в Монгольском Алтае. ${ }^{4}$ Остатки лука были обнаружены и в могиле 5 кургана Аржан-2. Но, судя по реконструкции, это был именно «скифский» лук, то есть короткий рекурсивный с рефлексной рукоятью. ${ }^{5}$ Он был длиннее - 117 см, но длина тетивы составляла 95 см.

Найден колчан из шкуры лошади с 10 стрелами с хорошо сохранившимися древками из

\footnotetext{
${ }^{4}$ См.: Молодин В. И., Парцингер Г., Цэвээндорж Д. Замерзшие погребальные комплексы пазырыкской культуры на южных склонах Сайлюгема (Монгольский Алтай). М., 2012. C. $466,467$.

${ }^{5}$ См.: Годерхард Э., Шелленберг Х. М. Луки скифского времени // Чугунов К. В., Парцингер Г., Наглер А. Царский курган скифского времени Аржан-2 в Туве. Новосибирск, 2017. C. $220-232$.
} 


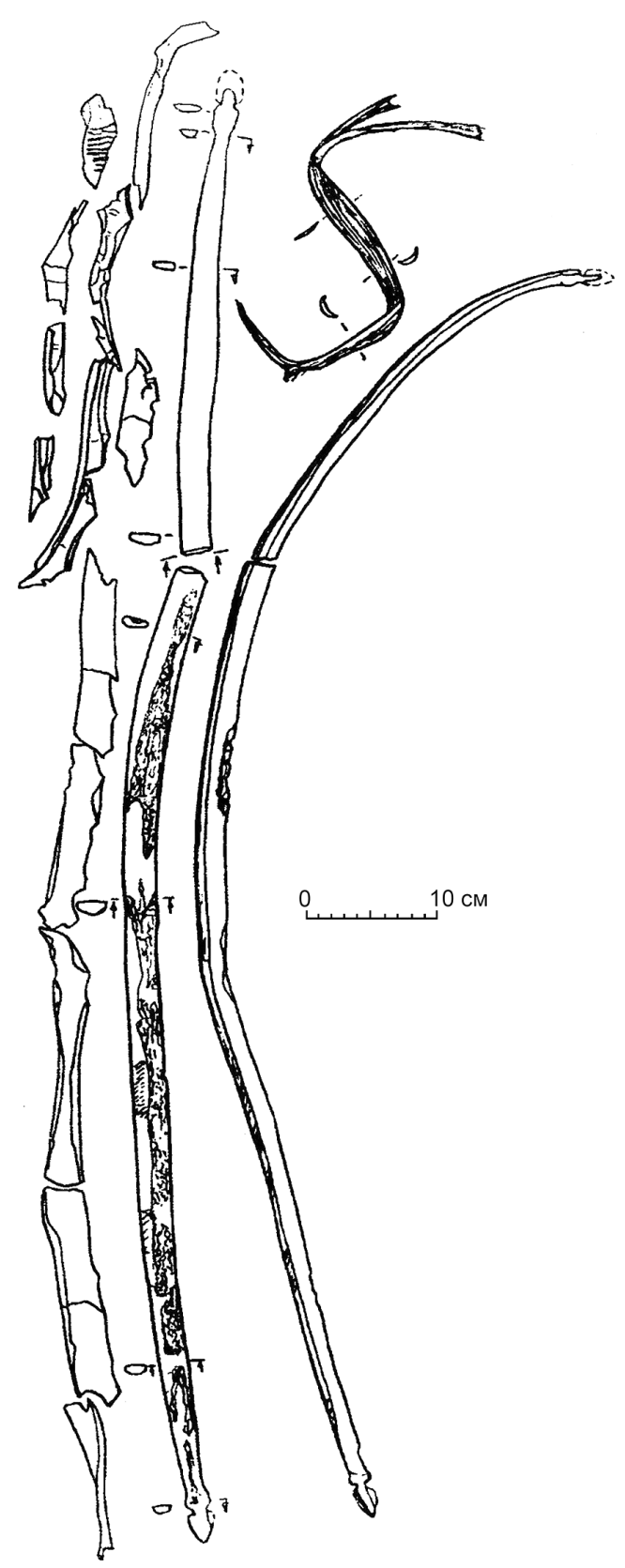

Рис. 2. Могильник Сарыг-Булун, могила 5. Лук

березы и лиственницы. Длина стрел от 65 до 70 см. На конце древок сделан специальный вырез под тетиву и красной краской нанесен орнамент в виде S-видных и пламевидных фигур (рис. 3). Подобный орнамент представлен на древках стрел из третьего Пазырыкского кургана. ${ }^{6}$ В кургане Аржан-2 на некоторых древках стрел из могилы 5 также представлена роспись. В основном это голубые и красные ленты с полосками и точками. ${ }^{7}$ Но интересно, что лук из Аржана-2 был украшен золотыми накладками

\footnotetext{
${ }_{6}^{6}$ См.: Руденко С. И. Культура населения Центрального Алтая в скифское время. М.; Л., 1960. Рис. 126.

7 См.: Чугунов К. В., Парцингер Г., Наглер А. Указ. соч. С. 52.
}

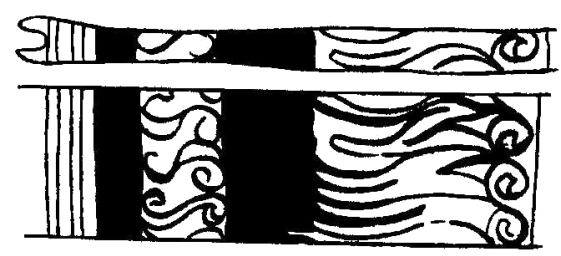

Рис. 3. Могильник Сарыг-Булун, могила 5. Роспись на древке стрел

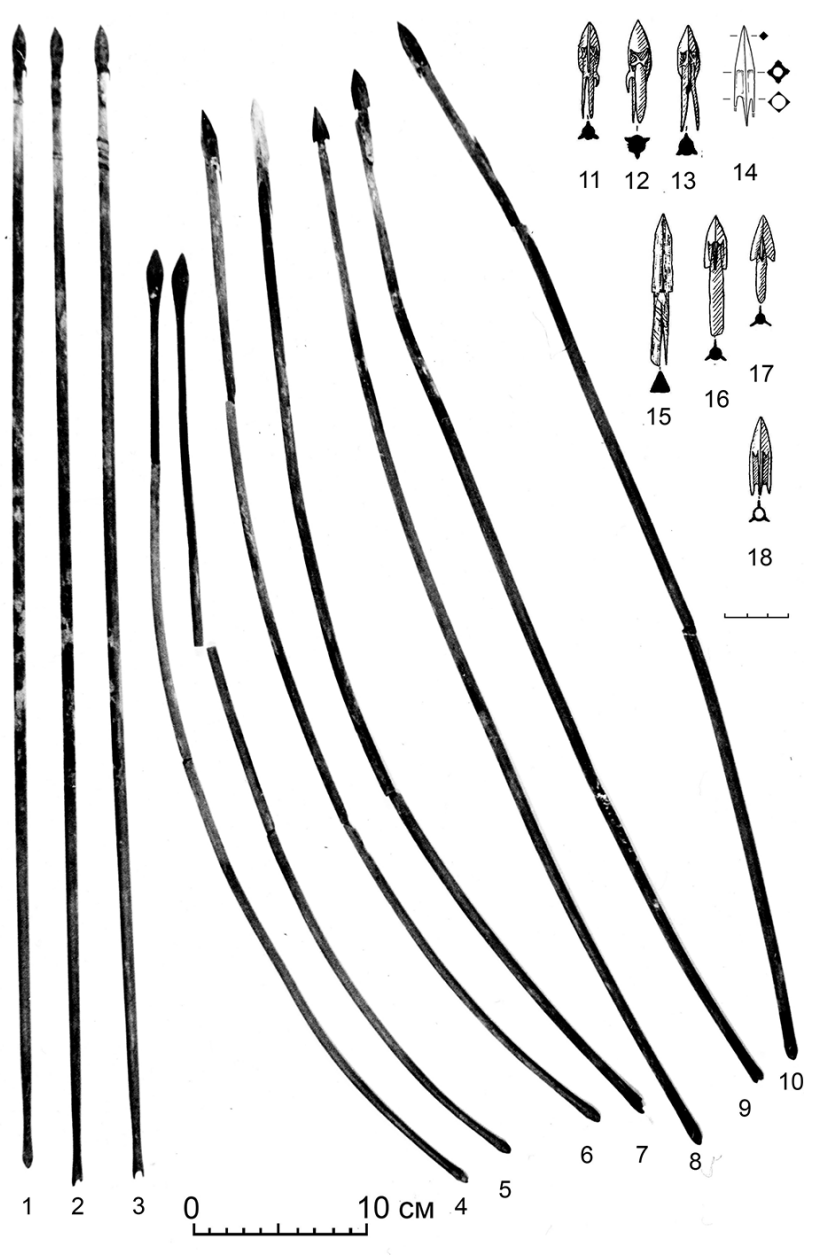

Рис. 4. Могильник Сарыг-Булун, могила 5. Стрелы

в виде пламевидного орнамента, аналогичного росписям на сарыг-булунских стрелах.

Особую ценность для культурно-хронологической атрибуции комплекса представляют наконечники стрел (рис. 4). Две стрелы были цельнодеревянными, круглыми в сечении томары (рис. 4, 4, 5). Одна стрела оказалась оснащена трехгранным черешковым костяным наконечником с плоским насадом, покрытым косыми насечками (рис. 4, 15). Остальные наконечники стрел бронзовые. Один - черешковый трехлопастной (рис. 4, 17). Один черешковый трехгранно-трехлопастной с башневидной сводчатой головкой и треугольными 
вырезами в гранях (рис. 4, 16). Два - втульчатых трехгранных со сводчатой головкой и опущенными ниже втулки жальцами и выемками (вильчатой и прямоугольной) на гранях (рис. 4, $14,18)$. Три стрелы с трехгранно-трехлопастными листовидными наконечниками имели раздвоенную втулку (зажимные) и кривой шип в ее основании (рис. $4,11-13$ ). Они украшены литым криволинейным узором. Наконечники стрел из Сарыг-Булуна подробно проанализированы в нескольких работах К. В. Чугуновым, ${ }^{8}$ который сравнивает их с колчанными наборами из Аржана-2, Чинге-Тея I и другими памятниками раннескифского времени. Стрелы из могилы 5 Сарыг-Булуна ближе к комплексам из Чинге-Тея, в то время как комплекс из более ранней могилы 2 находит аналогии с ранними наборами Аржана-2.9

За спиной погребенной лежал чекан втульчатый с петлевидным обухом и круглым в сечении бойком, насаженный на длинную (70 см) рукоять, к которой он крепился деревянной шпонкой (рис. 5). Такой же шпонкой крепился и вток. Размеры чекана - длина 14 см, высота 4 см. Вток имеет копьевидную заостренную форму и фигурный вырез (возможно, след литейного брака), размеры - длина 6,5 cм, ширина 3 см. Бронзовые втульчатые чеканы характерны для алды-бельской культуры, но для большинства из них характерно размещение стилизованной головки хищной птицы между бойком и рукоятью, чего нет на рассматриваемом экземпляре. Относительные аналогии он находит в подгорновской культуре в Минусинской котловине, где подобные находки датируются VII-VI вв. до н. э., но петлевидная форма обуха здесь не встречается. ${ }^{10}$ В этой же культуре находит прямые аналогии и нож, который был зафиксирован при рентгенографическом обследовании (см. ниже). Точно такой же нож с небольшой петлей для

\footnotetext{
8 См.: Чугунов К. В. Бронзовые наконечники стрел скифского времени Тувы // Мировоззрение. Археология. Ритуал. Культура. СПб., 200о. С. 215-234; Он же. Дискретность постройки «царских» мемориалов Тувы и хронология раннескифского времени // "Terra Scythica": материалы междунар. симпоз. "Terra Scythica". Новосибирск, 2011. С. 367, 368; Он же. Аржан-2: реконструкция этапов функционирования погребально-поминального комплекса и некоторые вопросы его хронологии // Рос. археол. ежегод. СПб., 2011. № 1. С. 314, 315.

9 Он же. Классификация стрел К. Ф. Смирнова и колчанные наборы раннескифского времени восточной зоны как хронологический индикатор // Скифия и Сарматия. М., 2019. С. $38,39$.

${ }_{10}$ См.: Вадецкая Э. Б. Археологические памятники в степях среднего Енисея. Л., 1986. С. 102-106, табл. VI, 12; Марсадолов Л. С. Салбыкский культурно-хронологический комплекс в истории древней Хакасии // Теория и практика археологических исследований. 2015. Т. 11, № 1. Рис. 1. 3, 1. 4, 1-5.
}

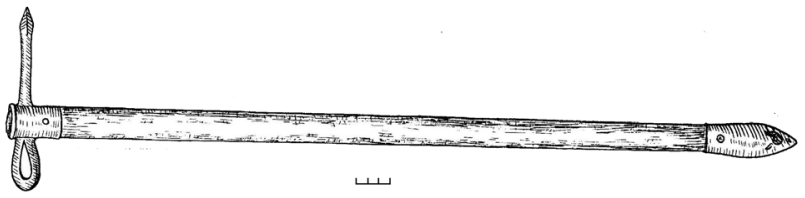

Рис. 5. Могильник Сарыг-Булун, могила 5. Чекан

привешивания был обнаружен в раннетагарском могильнике Казановка-3 (курган 3, ограда Б, могила 2) в юго-западной части Хакасии (Аскизский район), ${ }^{11}$ комплекс которого по результатам радиоуглеродного анализа датируется X - серединой VII в. до н. э. ${ }^{12}$

На основании всех аналогий артефактам из могилы ребенка ее сооружение можно отнести к концу VII - началу VI в. до н. э. Данная публикация посвящена введению в научный оборот результатов нового изучения этой мумии методами радиографии и генетики.

\section{Рентгенографическое исследование мумии ребенка}

Основой исследования стал метод микрофокусной рентгенографии, использующий проекционное увеличение изображения и последующую компьютерную обработку рентгеновских снимков. ${ }^{13}$ Обычно мумифицированные останки человека исследуют с помощью компьютерной томографии, однако, если сохранность или размеры объекта не позволяют поместить его в гентри томографа, микрофокусная рентгенография остается наиболее доступным, надежным и качественным способом изучения внутренней структуры. При исследовании скелетированных останков рентгенографическая фиксация индикаторов физиологического стресса позволяет проследить изменение качества жизни у средневекового населения на протяжении нескольких веков. ${ }^{14}$

Цель нового исследования - на основе цифровых изображений, полученных при помощи микрофокусной рентгенографии, описать сохранность скелетных останков, уточнить определение биологического возраста, оценить

\footnotetext{
$\overline{11}$ Выражаем большую благодарность $Н$. А. Боковенко, предоставившему данную информацию.

${ }_{12}$ См.: Евразия в скифскую эпоху: радиоуглеродная и археологическая хронология / Алексеев А. Ю. [и др.]. СПб., 2005. C. 117 .

${ }^{13}$ См.: Применение микрофокусной рентгенографии при диагностике заболеваний древнего человека/Бужилова А. П. [и др.] // Петербургский журнал электроники. 2008. № 2-3. C. $152-162$.

${ }^{14}$ См.: Медникова М. Б., Энговатова А. В., Тарасова А. А. Диахронные изменения качества жизни населения Ярославля в XIII-XVII вв. по данным радиологии // РА. 2015. № 3. С. 94-106.
} 
параметры физического развития и возможное наличие палеопатологических проявлений. Кроме того, рассмотрение некоторых фенотипических особенностей, выявленных в процессе рентгенографического исследования, в контексте данных палеогенетики позволит сделать выводы о происхождении этого индивидуума, похороненного в могильнике Сагыр-Булун.

\section{Методика микрофокусной рентгенографии}

Методика получения рентгеновских изображений мумий в неспециализированных условиях была предложена сотрудниками кафедры ЭПУ СПбГЭТУ «ЛЭТИ». ${ }^{15}$ Для ее реализации в качестве источника излучения был использован микрофокусный рентгеновский аппарат РАП-10оМ (ЗАО «ЭЛТЕХ-Мед», Технопарк СПбГЭТУ «ЛЭТИ») в портативном исполнении. В качестве приемника изображения применялась система визуализации на основе экрана с фотостимулируемым люминофором. Полученные цифровые рентгеновские изображения обрабатывались с помощью оригинального программного обеспечения. ${ }^{16}$

Вследствие конечных размеров кассеты с экраном для получения изображения всей мумии последовательно было выполнено и проанализировано около полутора десятков рентгеновских снимков отдельных областей ее тела.

\section{Сохранность скелета}

Серия снимков, выполненная в разных проекциях и с разным коэффициентом увеличения изображения, позволила уточнить степень сохранности краниальных и посткраниальных останков индивидуума. Хорошо сохранились череп и нижняя челюсть. При этом резцы верхней и нижней челюсти отсутствуют в альвеолярном сочленении (рис. 6). На фронтальном снимке нижней челюсти слева видны лунки передних зубов. Центральная часть верхней челюсти демонстрирует обширное разрушение, распространяющееся почти вплоть до нижнего края грушевидного отверстия. Шейный отдел позвоночника - в анатомическом порядке, грудные позвонки смещены (очевидно, в процессе извлечения и транспортировки

\footnotetext{
${ }^{15}$ См.: Микрофокусная рентгенография: результаты исследований Санкт-Петербургского государственного электротехнического университета «ЛЭТИ» им. В. И. Ульянова (Ленина) / Потрахов Н. Н. [и др.] // Территория NDT. 2016. № 3. С. 54-57. ${ }^{16}$ Cm.: New Methods for Digital Processing of Microfocus X-Ray Images / Staroverov N. E. [et al.] // Biomedical Engineering. 2019. Vol. 52, № 6. C. 435-438.
}

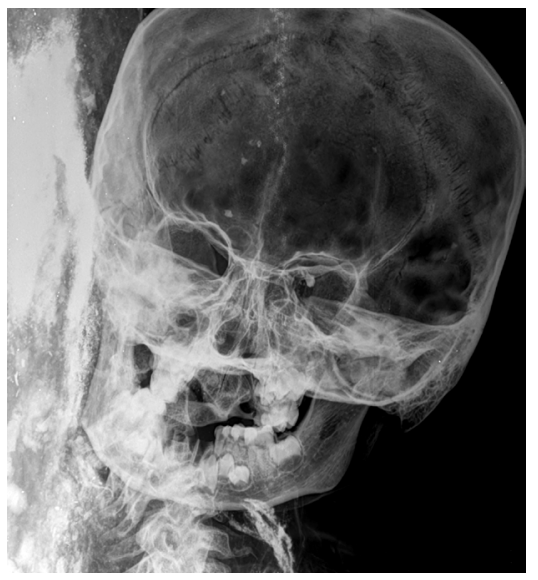

Рис. 6. Фронтальный снимок черепа

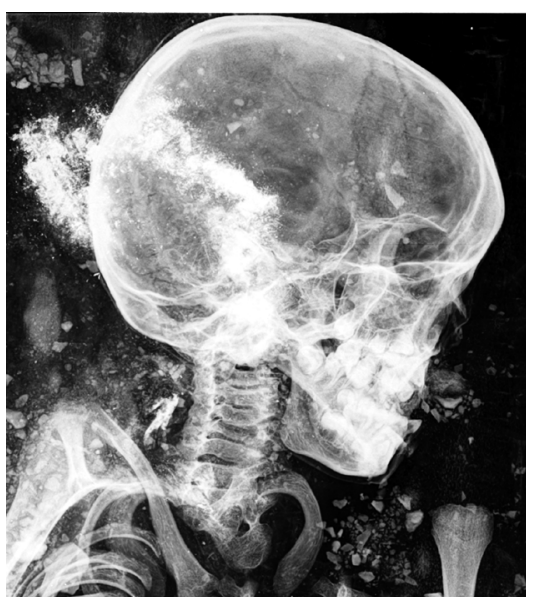

Рис. 7. Снимок черепа в боковой проекции

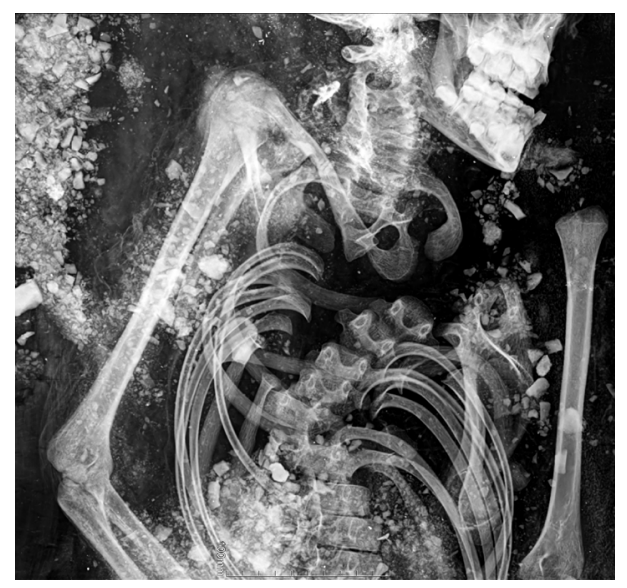

Рис. 8. Панорамный снимок шейного отдела позвоночника, грудной клетки и плечевых костей

мумии) (рис. 7). Сохранились парные ключицы, плечевые, лучевые, локтевые кости, кости кисти в анатомическом сочленении. На снимке туловища видно, что наибольшие посмертные изменения претерпел грудной отдел позвоночника, 6 нижних позвонков которого остались в сочленении, но смещены, 5 верхних грудных позвонков здесь отсутствуют, первый грудной развернут примерно на 90 градусов (рис. 8). 


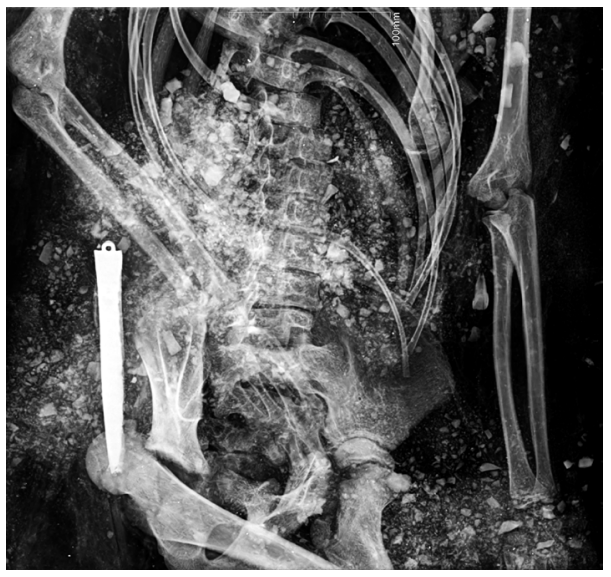

Рис. 9. Панорамный снимок тазовой области

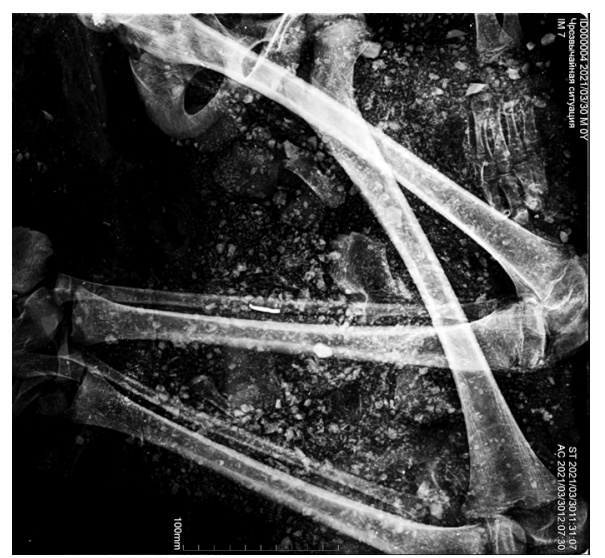

Рис. 10. Панорамный снимок нижних конечностей

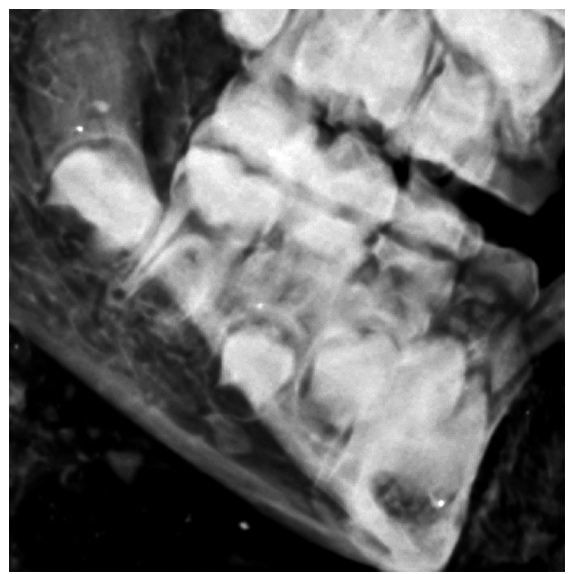

Рис. 11. Снимок нижней челюсти мумии ребенка в боковой проекции с увеличением

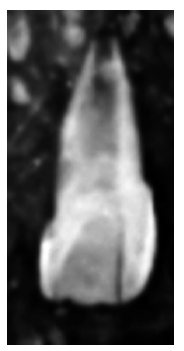

Рис. 12. Снимок изолированного резца (закладки) с не до конца сформированным корнем
Поясничный отдел и тазовые кости без смещения (рис. 9). О том, что мумия могла быть повреждена в процессе транспортировки, говорит молочный однокоренной зуб в области третьего поясничного позвонка (резец?), а также более крупный постоянный резец с незакрытым корнем в области левого предплечья и молочный клык на уровне середины правой большеберцовой кости (рис. 10). Длинные кости верхней конечности и кости обеих кистей сохранили анатомическое сочленение. Обе ноги были согнуты в коленном суставе под углом до 45 градусов, их кости сохранили анатомический порядок.

\section{Определение биологического возраста}

На фронтальном снимке черепа и в боковой проекции отчетливо видны две генерации зубов - молочных, находящихся в альвеолярном сочленении, и постоянных, представленных коронками, сформированными в разной степени. В толще нижней челюсти отчетливо видны закладка клыка (средний возраст прорезания у девочек - 8,8+o,63 года), закладки премоляров с полностью не сформировавшимися корнями (оба зуба прорезаются после 9 лет). Прорезался первый постоянный моляр нижней челюсти, средние сроки выхода которого у девочек оцениваются в среднем в $5+0,39$ года. ${ }^{17}$ На снимке в боковой проекции хорошо видны глубоко сидящие в теле нижней челюсти закладки постоянных резцов, что соответствует возрасту 6 лет+24 месяца ${ }^{18}$ (рис. 11).

Как отмечалось выше, в области предплечья виден крупный постоянный резец с незакрытым, но длинным корнем (закрывается к 8 годам, рис. 12). Исходя из общей картины, скорее всего, он оказался в таком неожиданном месте после посмертного разрушения верхней челюсти. Судя по увеличенному рентгеновскому изображению, жевательная поверхность резца имеет волнистый край, обычно не наблюдаемый уже к 8 годам. Не исключено, что это полностью готовый к выходу верхний резец. На снимке он имеет лопатообразную форму.

В целом зубной возраст ребенка соответствует интервалу 6-7 лет, что совпадает с началом периода второго детства (ранее считалось, что могила принадлежит подростку

${ }^{17}$ Cm.: Liversidge H. M., Herdeg B., Rosing F. W. Dental estimation in non-adults. A review of methods and principles // Dental Anthroplogy, Fundamentals, Limits and Prospects. Vienna, 1998. P. 419-422.

${ }_{18}$ CM.: Ubelaker D. H. Human skeletal remains: excavation, analysis, interpretation. Washington, D.C., 1989. Fig. 164. 
12-14 лет $\left.{ }^{19}\right)$. Благодаря палеогенетическому исследованию удалось определить женский пол индивидуума.

\section{Определение параметров физического развития}

Определение продольных размеров трубчатых костей на рентгеновских снимках оказалось затруднено из-за того, что кости в момент съемки не прилегали непосредственно к приемнику - кассете с экраном, на которую проецировалось изображение, и, кроме того, по-видимому, конечности располагаются под небольшим углом к горизонтальной поверхности.

Эти проекционные искажения привели к тому, что реконструированная диафизарная длина левой бедренной кости составила $36,8 \mathrm{~cm}$, что соответствует параметрам физического развития 10-11-летних детей. ${ }^{20}$ Определенная с помощью уравнения регрессии для бедренной кости длина тела ребенка составила, таким образом, 149,7 см, что представляется слишком большой величиной. Поскольку приблизительное измерение длины бедренной кости, скрытой под мягкими тканями мумии, составило около $28 \mathrm{~cm}$, очевидно, что в этом случае мы не можем полагаться на рентгенографические измерения для определения длины тела ребенка.

Для сравнения, длина тела 7-летних тувинских девочек, обследованных в 1978-1984 гг. в поселке Мугур-Аксы и в Тоджинском районе, составляла 110,3 см и 117,4 см, а их вес тела 19,3 кг и 20,13 кг. ${ }^{21}$

Более адекватными с точки зрения соответствия зубному возрасту выглядят параметры развития левой большеберцовой кости, лишенной мягких тканей, которые можно было определить in situ. Ее диафизарная длина 21,6 см несколько ниже среднего значения для девочек 6 лет, рожденных между 1915 и 1967 гг., ${ }^{22}$ или соответствует размерам акцелерированных 6-летних американских детей из обследования 1967 г. ${ }^{23}$

В области нижних метафизов плечевых костей прослеживаются хорошо сформирован-

\footnotetext{
19 См.: Уникальное захоронение ребенка... С. 379-406.

${ }^{20}$ Сравнительные данные по: Maresh M. M. Measurements from roentgenograms // Human growth and development. Springfield, 1970. P. 157-200.

${ }_{21}^{21}$ См.: Антропоэкология Центральной Азии. М., 2005. С. 154, 163.

${ }^{22}$ Cм.: Maresh M. M. Op. cit.

${ }^{23}$ Cм.: Gindhardt P. Growth standards for the tibia and radius in children aged one month through eighteen years // American Journal of Physical Anthropology. 1973. Vol. 39, iss. 1. P. 41-48.
}

ные балки костного вещества. Это свидетельствует о регулярных нагрузках на пояс верхних конечностей, обычно не характерных для современных детей этой возрастной группы.

По рентгеновским снимкам левых плечевой и бедренной костей, выполненных в переднезадней проекции, было возможно определить индексы компактизации боковых стенок на уровне середины диафиза - 57,14 и 43,47 соответственно. Это различие отражает топографию физических нагрузок на скелет.

\section{Наличие индикаторов физиологического стресса и палеопатологий}

Оценка присутствия палеопатологических проявлений была ограничена отсутствием доступа к скелетированным останкам ребенка.

В области нижних метафизов бедренных костей наблюдаются линии Гарриса, видимые на всем протяжении, - следствие физиологического стресса в результате резкого голодания или лихорадочного состояния, испытанного не менее чем за год до смерти (рис. 13А). На снимке правой большеберцовой кости этот серьезный негативный эпизод в жизни ребенка запечатлен в виде резорбированной линии, кроме того, здесь, возможно, присутствуют слабые последствия двух более поздних стрессов (рис. 13Б).

Признаков переломов, других травм и очагов деструкции, которые можно было бы связать с различными патологическими состояниями, на рентгеновских снимках не наблюдается.

На фронтальном снимке левой бедренной кости в области метафиза можно видеть периостальные изменения («вельветовая поверхность»), слоистость структуры компактного вещества (рис. 14). Метафиз расширен. Совокупность этих признаков можно трактовать как возможные проявления недостатка витамина D (рахит).. ${ }^{24}$ Диагноз подтверждается заметным искривлением диафиза левой лучевой кости, фиксируемым на рентгеновском снимке с увеличением изображения. Вместе с тем диафизы бедренных и большеберцовых костей прямые, шейка бедренной кости имеет высокий угол. Отсутствие следов остеомаляции и повышенной скелетной пластичности, обычно сопровождающей витаминную недостаточность, в данном случае можно соотнести с ранним при-

\footnotetext{
24 См.: Медникова М. Б. Биоархеология детства в контексте раннеземледельческих культур Балкан, Кавказа и Ближнего Востока. М., 2017. С. 87-89.
} 
A

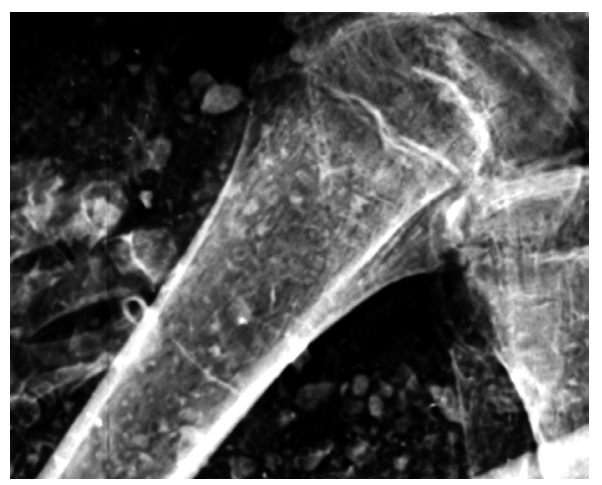

Б

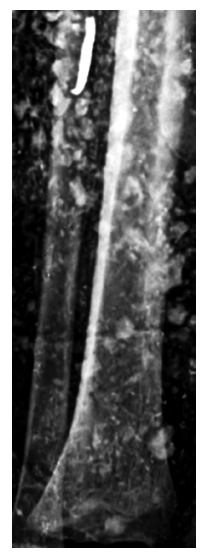

Рис. 13. А - линия Гарриса на рентгенограмме метафиза бедренной кости (боковая проекция);

Б - резорбированные линии Гарриса в нижнем метафизе большеберцовой кости

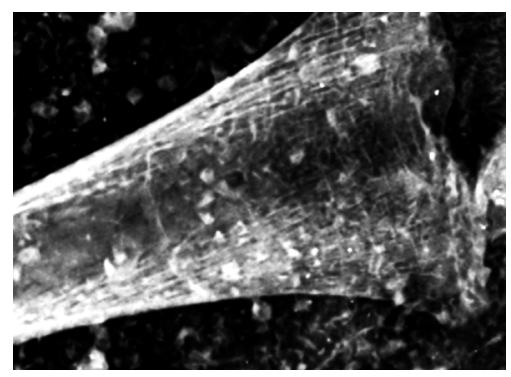

Рис. 14. Периостальные изменения и слоистость в нижнем метафизе бедренной кости

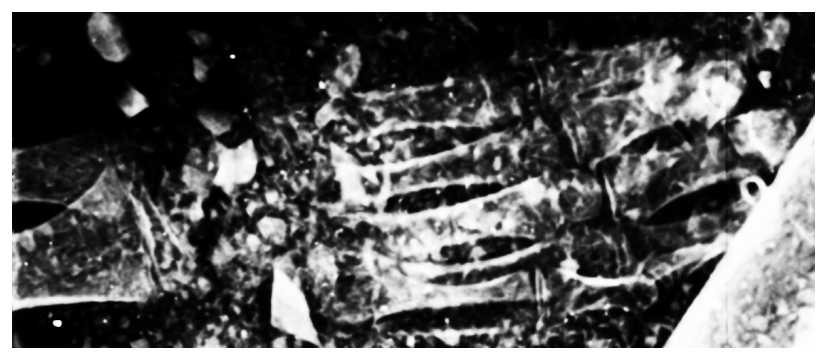

Рис. 15. Увеличенный снимок левой кисти с металлическим кольцом (?)

общением ребенка к верховой езде, компенсировавшей давление веса тела на нижние конечности и сопутствующую деформацию.

\section{Артефакты, обнаруживаемые на рентгеновском изображении мумии}

В области медиальной фаланги четвертого луча левой кисти - металлическое кольцо (рис. 15). Обычно кольца носят ниже, на уровне проксимальных фаланг, следовательно, это украшение было надето после смерти ребенка (на концевую фалангу?) или сдвинулось в дистальном направлении после деформации мягких тканей, скорее всего, при транспортировке мумии. Судя по размерам кольца, не исключено, что оно было надето на мизинец. Но также оно могло быть частью сместившейся ременной гарнитуры (например, ворворка), так как ношение колец не характерно для данной культуры.

Металлический артефакт в виде «скобки» выявляется на уровне центральной части правой малоберцовой кости. На уровне кисти правой (согнутой в локтевом суставе) руки имеется металлический предмет в форме ножа с ушком для подвешивания. Его острие достигает уровня шейки правой бедренной кости (см. рис. 9).

\section{Социальный статус ребенка}

Помимо богатого погребального инвентаря о социальном статусе этой девочки могут свидетельствовать особенности ее соматического развития. Обращает на себя внимание совпадение зубного возраста ребенка, наиболее точно отражающего биологический возраст, и размеров тела, соответствующих параметрам развития крупных акцелерированных детей из американской популяции XX в. В палеопопуляциях часто наблюдается отставание физического развития детей ранней возрастной категории, связанное прежде всего с пищевыми стрессами. Значит, несмотря на отдельные неблагоприятные эпизоды, приводившие к кратковременной остановке процесса роста, организм девочки, погребенной в могильнике Сарыг-Булун, обладал достаточной резистентностью, по-видимому, обеспеченной полноценным питанием. Это может быть интерпретировано как косвенное подтверждение достаточно высокого социального статуса. Пищевой стресс, связанный с недостатком витамина D и приведший к манифестациям рахита, очевидно, носил сезонный характер и усугублялся в зимнее время, когда, возможно, и скончался этот ребенок. Поскольку в последнее время в научной литературе обсуждается статус витамина D как стероидного гормона, имеющего ядерный гормональный рецептор и обнаруживающего тесную связь с иммунитетом, можно предположить, что организм девочки на момент смерти был ослаблен и она могла скончаться от присоединившейся инфекции.

В образце костной ткани ребенка были определены значения показателей, соответствовавших диете, преимущественно основанной на растениях С4 типа фотосинтеза (скорее всего, просе; $\delta 13 \mathrm{C}-14,59)$. Значение $\delta 15 \mathrm{~N}$ указывало на то, что рацион преимущественно состоял из растительной пищи. ${ }^{25}$ Было отмечено,

${ }_{25}$ См.: Уникальное захоронение ребенка... С. 391. 
что этот результат не противоречит данным, полученным при предшествующем изотопном исследовании особенностей питания погребенных в могильнике Аймырлыг. ${ }^{26}$

Однако более детальное рассмотрение публикации результатов исследования выборки Аймырлыга (суммарно 21 индивид, 9 женщин и 12 мужчин), выполненного в ирландской лаборатории, показывает существование различий. Если среднее значение дельта изотопа углерода в группе Аймырлыга $(-15,3 \pm 1,25 \%$ ) подтверждает употребление в пищу проса этими тувинскими кочевниками, то высокое

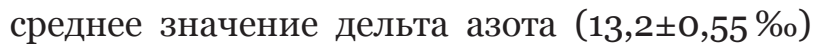
отражает постоянное употребление белков животного происхождения.

Состав рациона девочки из Сарыг-Булуна отличался от питания популяции Аймырлыга малым потреблением протеинов ( $\delta 15 \mathrm{~N}-11,05)$, что необычно для ребенка из популяции кочевников-скотоводов. Возможно, это отличие было обусловлено возрастной или гендерной спецификой питания или даже следованием неким иным культурным традициям, связанным с происхождением и статусом ребенка.

Этот статус определялся и принадлежностью к определенной возрастной категории. Во многих обществах традиционной культуры возраст около 6 лет, знаменуемый появлением первых постоянных зубов, был сопряжен с инициациями и прохождением специфических обрядов. Наконец, генетически подтвержденный пол ребенка открывает возможность для обсуждения гендерных аспектов в социуме скотоводов Южной Сибири раннего железного века.

\section{Генетические исследования}

Для генетического анализа в лабораторию были предоставлены биологические материалы: 3 зуба и кусок кожи от ребенка из могильника Сарыг-Булун. Образцы зубов очищали в ультразвуковой ванне с гипохлоритом натрия и ультрачистой водой. Далее зубы облучались УФ по 2 минуты с каждой стороны. Образцы измельчали до состояния муки в шаровой мельнице. Выделялась ДНК из о,2 г костного порошка в соответствии с протоколом. ${ }^{27}$ Таргетное секве-

\footnotetext{
${ }^{26}$ CM.: Iron Age pastoral nomadism and agriculture in the eastern Eurasian steppe: implications from dental palaeopathology and stable carbon and nitrogen isotopes / Murphy E. M. [et al.] // Journal of Archaeological Science. 2013. Vol. 40, iss. 5. P. 2547-2557.

${ }^{27}$ CM.: Complete mitochondrial genome sequence of a Middle Pleistocene cave bear reconstructed from ultrashort DNA fragments / Dabney J. [et al.] // Proceedings of the National Academy of Sciences. 2013. Vol. 110, iss. 39. P. 15758-15763.
}

нирование по методу NGS гипервариабельных сегментов (ГВС) I-III митохондриальной ДНК девочки было проведено с помощью набора реагентов PowerSeq ${ }^{\mathrm{TM}}$ CRM (Promega).

Контроль качества полученных библиотек производили на приборе Agilent Bioanalyzer 2100 с помощью набора реагентов High Sensitivity Kit (Agilent Technologies) по протоколу производителя.

Секвенирование по методу NGS проводилось на секвенирующей платформе Miseq (Illumina). Подготовка образцов и запуск осуществлялись согласно протоколам Illumina (Reagent Kit v2 300-cycles). Методика биоинформационного анализа NGS приведена в ранее опубликованной статье. ${ }^{28}$

Секвенирование осуществлено с помощью таргетного NGS ГBC I-III. Выявленные мутации митохондриального генома этой девочки приведены в табл. 1. Данные мутации определяют вероятную гаплогруппу D4g2. Гаплогруппа D имеет преимущественно восточноевразийское распределение в современных популяциях. В Восточной Азии гаплогруппа D (15\%) входит в число наиболее распространенных. Еще более она типична для Северной Азии (16\%). Широко распространена она и в Центральной Азии (13\%). В других частях Азии и в Европе гаплогруппа D редка - частота не превышает 1-2\%. В Европе - в регионе между Балтийским и Баренцевым морями - находят специфический вариант гаплогруппы D, достигающий $5 \%$ в некоторых популяциях. ${ }^{29}$

В палеогенетических исследованиях сибирского населения скифской эпохи анализ митохондриальной ДНК выявил наличие в его генофонде в равной степени как западно-евразийских (H, H14b2, H6a1a1, HV6, HV14a, T2d2, U4a1a, U5a2a1 и U5a1f1), так и восточно-евразийских гаплогрупп (D4j7, C4a1a3, C4d, F1b1b и G2a1). ${ }^{30}$ В то же время у скифов Европы большая часть митохондриальных линий относится к западно-евразийским гаплогруппам с примесью восточно-евразийских гаплогрупп. ${ }^{31}$ Таким образом, население скифского времени

\footnotetext{
${ }_{28}$ См.: Уникальное захоронение ребенка... С. 398, 399.

${ }_{29}$ См.: Балановский О. П. Генофонд Европы. М., 2015.

$3^{\circ}$ Cм.: Genetic kinship and admixture in Iron Age Scytho-Siberians /

Mary L. [et al.] // Human Genetics. 2019. Vol. 138 (4). P. 411-423.

${ }^{31}$ Cm.: Genome-wide patterns of selection in 230 ancient Eurasians / Mathieson I. [et al.] // Nature. 2015. Vol. 528, iss. 7583. P. 499-503; Investigating kinship of Neolithic post-LBK human remains from Krusza Zamkowa, Poland using ancient DNA / Juras A. [et al.] // Forensic Science International: Genetics. 2017. Vol. 26. P. 30-39.
} 
РЕЗУЛЬТАТЫ ТАРГЕТНОГО СЕКВЕНИРОВАНИЯ МИТОХОНДРИАЛЬНОЙ ДНК ДЕВОЧКИ ИЗ ПОГРЕБЕНИЯ 5 МОГИЛЬНИКА САРЫГ-БУЛУН

\begin{tabular}{|c|c|}
\hline $\begin{array}{c}\text { Мутации, обнаруженные в ГВС I-III } \\
\text { митохондриальной ДНК }\end{array}$ & $\begin{array}{c}\text { Предсказание гаплогрупп } \\
\text { митохондриальной Днк }\end{array}$ \\
\hline $\begin{array}{l}\mathrm{A} 73 \mathrm{G}, \mathrm{T} 146 \mathrm{C}, \mathrm{T} 152 \mathrm{C}, \mathrm{A} 263 \mathrm{G}, \mathrm{C} 298 \mathrm{~T}, \mathrm{C} 431 \mathrm{~T}, \\
\mathrm{C} 16067 \mathrm{~T}, \mathrm{C} 16069 \mathrm{~T}, \mathrm{C} 16223 \mathrm{~T}, \mathrm{~T} 16362 \mathrm{C}, \mathrm{T} 16519 \mathrm{C}, \mathrm{G} 16526 \mathrm{~A}\end{array}$ & $\mathrm{D} 4 \mathrm{~g} 2$ \\
\hline
\end{tabular}

Сибири, в том числе девочка из Сарыг-Булуна, имело бо́льшие азиатские влияния, чем европейские скифы.

\section{Происхождение по данным антропологического источника}

Применение микрофокусной рентгенографии позволило обнаружить сформированную закладку верхнего резца, имевшего, по всей видимости, лопатообразную форму. Такая форма резцов традиционно рассматривалась как ценный расово-диагностический признак, частота встречаемости которого в некоторых современных популяциях монголоидной расы достигает $100 \%$, в то время как в отдельных группах европеоидов падает до о \%. ${ }^{32}$ Следует добавить, что, хотя лицевой скелет этого ребенка окончательно не сформирован, рассмотрение рентгеновского изображения (рис. 7) позволяет предположить значительную ослабленность горизонтальной профилировки, типичную для монголоидного населения.

Т. А. Чикишевой на основании вариаций краниометрических и одонтологических признаков были рассмотрены тенденции изменения антропологического состава ранних кочевников Тувы. ${ }^{33}$ Главная ось этих модификаций в эпоху раннего железа определяется благодаря инфильтрации морфологических особенностей, дифференцирующих европеоидные и монголоидные комплексы. Описывая одонтотип ранних кочевников Тувы, для которого базовым рассматривается характерный для алды-бельского Аржана-2, Т. А. Чикишева акцентировала внимание на сочетании признаков европеоидного компонента и маркеров монголоидности (в том числе медиальных резцов лопатообразной формы). Последствия восточного импульса, изменившего антропологические особенности тувинских кочевников и связанного с морфологическим комплексом дальневосточной локальной расы, основной

\footnotetext{
32 См.: Этническая одонтология СССР. М.; Л., 1979.

33 См.: Чикишева Т. А. Динамика антропологической дифференциации населения юга Западной Сибири в эпохи неолита - раннего железа. Новосибирск, 2012.
}

у населения Северного Китая, Т. А. Чикишева соотносит с финальным этапом алды-бельской культуры в V в. до н. э. и с началом гунно-сарматского периода (конец III в. до н. э.). Возвращаясь к результатам исследования мумии девочки из Сарыг-Булуна, мы можем констатировать, что инициальное проникновение обитателей Северного Китая в Туву происходило на несколько веков ранее, чем предполагалось.

$$
* * *
$$

Погребальный комплекс могильника СарыгБулун находит прямые соответствия с исследованными в Турано-Уюкской котловине элитными погребально-поминальными комплексами раннескифского времени Аржан-2 и ЧингеТей I. Разнообразный погребальный инвентарь говорит о высоком статусе захороненных здесь людей, которые могли принадлежать к местной элите. Необычное захоронение девочки с набором оружия, который характерен для мужских погребений, вызывает особый интерес. Специальных исследований об отношении к детям в раннескифское время в Туве пока нет. Погребения младенцев в алды-бельских курганах зачастую совершаются за пределами или около оград, нередки случаи захоронения детей (от 1,5 до 3 лет) вместе с мужчинами (могильник Бай-Даг 6), но в большинстве случаев детей хоронили со взрослыми, в подростковом и более раннем возрасте им в могилы помещали инвентарь, в основном отдельные предметы, но никогда не клали комплект оружия. С 6-7 лет дети становились деятельными помощниками в ведении хозяйства и других жизненно важных сферах, переходя на следующую ступень в иерархии своего рода/семьи. Эти социальные роли подтверждают и данные по этнографии детства у тувинцев, монголов и хакасов. ${ }^{34}$

\footnotetext{
34 См.: Сундуй Г. В. Мир детства кочевой Азии: опыт духовно-нравственного воспитания. Кызыл, 2009. С. 109, 110; Викторова Л. Л. Система социализации детей и подростков у монголов, пути и причины трансформации ее элементов // Этнография детства. Традиционные формы воспитания детей и подростков у народов Восточной и Юго-Восточной Азии. М., 1983. С. 58, 59, 62; Кустова Ю. Г. Ребенок и детство в традиционной культуре хакасов. СПб., 200о. С. 72.
} 
Исследование мумии из раскопок могильника Сарыг-Булун методом микрофокусной цифровой рентгенографии позволило оценить сохранность скелетных останков и уточнить позу погребенной. На основании критериев развития зубной системы биологический возраст ребенка соответствует 6-7 годам, что совпадает с началом периода второго детства.

Девочка испытывала постоянные физические нагрузки на пояс верхних конечностей, определяемые рентгенографически. На снимках длинных костей нижней конечности выявлены не менее трех линий Гарриса - маркеров кратковременных остановок роста, отражающих неблагоприятные эпизоды в жизни ребенка. По-видимому, наиболее сильный физиологический стресс случился примерно за год до смерти. Выявлены морфологические последствия рахита (недостаток витамина D). Топография рахитических деформаций косвенно вновь подтверждает бо́льшие нагрузки на пояс верхних конечностей, и, возможно, раннее приобщение к верховой езде.

О достаточно высоком социальном статусе девочки из Сарыг-Булуна может свидетельствовать отсутствие отставания соматического развития (ее длина тела соответствует размерам акцелерированных 6-летних детей XX в.), не столь частое в палеопопуляциях. Определения биологического возраста по зубам и по степени развития скелетной системы у нее совпадают, значит, организму ребенка удавалось компенсировать перенесенные стрессы за счет полноценного питания. Ранее было установлено, что основу рациона девочки, по-видимому, составляло просо. Более детальное сопоставление с результатами изотопного анализа питания ранних тувинских кочевников из Аймырлыга позволяет оценить своеобразие диеты девочки из Сарыг-Булуна, не получавшей достаточного количества белков животного происхождения. Не исключено, что выявленная специфика определялась принадлежностью к определенной возрастной категории или следованию другой культурной традиции.

Наличие определенных фенотипических особенностей, выявленных в процессе рентгенографического исследования, и новые данные палеогенетики проливают свет на вопрос о происхождении 6-летней девочки из Сарыг-Булуна. Уплощенность горизонтальной профилировки лицевого скелета и лопатообразная форма верхнего постоянного резца сочетаются с присутствием гаплогруппы D4g2, что может говорить как о ее монголоидности, так и о метисном происхождении.

\section{Marina E. Kilunovskaya}

Candidate of Historical Sciences, Institute for the History of Material Culture of the RAS (Russia, Saint Petersburg)

E-mail: kilunmar@mail.ru

\section{Vladimir A. Semenov}

Candidate of Historical Sciences, Institute for the History of Material Culture of the RAS (Russia, Saint Petersburg)

E-mail: ranbov@yandex.ru

\section{Varvara S. Busova}

Researcher, Institute for the History of Material Culture of the RAS (Russia, Saint Petersburg) E-mail: kulturnijkarman@gmail.com

\section{Kharis Kh. Mustafin}

Candidate of Technical Sciences, Moscow Institute of Physics and Technology (Russia, Moscow)

E-mail: kh-mstf@yandex.ru

\section{Irina E. Alborova}

Candidate of Biological Sciences, Moscow Institute of Physics and Technology (Russia, Moscow)

E-mail: ira_teuchezh@mail.ru

\section{Nikolai N. Potrakhov}

Doctor of Technical Sciences, Saint Petersburg State Electrotechnical University (Russia, Saint Petersburg) E-mail:nn@eltech-med.com

\section{Nikolai E. Staroverov}

Assistant, Saint Petersburg State Electrotechnical University (Russia, Saint Petersburg)

E-mail: niko205st@mail.ru

\section{Maria B. Mednikova}

Doctor of Historical Sciences, Institute of Archaeology of the RAS (Russia, Moscow)

E-mail: medma_pa@mail.ru 


\section{MUMMIFIED BURIAL OF A CHILD FROM THE SARYG-BULUN BURIAL GROUND (CENTRAL TUVA). NEW DATA FROM ARCHAEOLOGY, RADIOGRAPHY, ANTHROPOLOGY AND GENETICS}

In 1988 on the right bank of the Yenisei River in Central Tuva, two burial mounds from the Saryg-Bulun burial ground were excavated. Burial № 5 attracted special attention of archaeologists - it contained the partially mummified remains of a child with a rich and unusual inventory (bow, quiver with arrows, a hat, engraving on a wooden handle) in a wooden block. A recent genetic analysis made it possible to establish, contrary to expectations, the female sex of an individual. Over the years, thanks to the development of natural scientific methods, it was possible to gradually obtain new data on the life and death of this girl. The article presents the results of an examination of the mummy by the method of microfocus digital radiography and a new paleogenetic study, which made it possible to determine the child's mitochondrial haplogroup (D4g2, which is widespread in East and Central Asia). The rich grave goods indicate the high status. Her biological age was determined $-6-7$ years. Indicators of physiological stress (Harris lines), the presence of noticeable physical exertion on the belt of the upper extremities during the child's life, and rickets were revealed. Radiography made it possible to detect artifacts invisible during a superficial examination, for example, a knife that was previously unnoticed in the deck. Genetic data are consistent with observations on the possible horizontal flattening of the girl's facial skeleton and the spatula-like shape of her upper incisor. The applied methods and the results obtained allow authors to look in a new light at the issues of the genesis of the Aldy-Bel culture and the theme of childhood in the early Scythian time.

Keywords: Early Iron Age, Tuva, mummy, microfocus radiography, childhood bioarchaeology, paleopathology, paleogenetics, mtDNA, targeted NGS

\section{REFERENCES}

Alekseev A. Yu., Bokovenko N. A., Vasiliev S. S. et al. Evraziya $v$ skifskuyu epokhu: radiouglerodnaya i arkheologicheskaya khronologiya [Eurasia in the Scythian era: radiocarbon and archaeological chronology]. Saint Petersburg: Teza Publ., 2005. (in Russ.).

Antropoekologiya Tsentral'noy Azii [Anthropoecology of Central Asia]. Moscow: Nauchnyy Mir Publ., 2005. (in Russ.). Balanovsky O. P. Genofond Evropy [The genofund of Europe]. Moscow: Tov-vo nauchn. izdaniy KMK Publ., 2015. (in Russ.).

Buzhilova A. P., Dobrovolskaya M. V., Mednikova M. B. et al. [Application of microfocus radiography in the diagnosis of diseases of ancient humans]. Peterburgskiy zhurnal elektroniki [Petersburg Electronics Journal], 2008, no. 2-3, pp. 152-162. (in Russ.).

Chikisheva T. A. Dinamika antropologicheskoy differentsiatsii naseleniya yuga Zapadnoy Sibiri $v$ epokhi neolita - rannego zheleza [Dynamics of anthropological differentiation of the population of the south of Western Siberia in the Neolithic - Early Iron Age]. Novosibirsk: IAiEt RAN Publ., 2012. (in Russ.).

Chugunov K. V. [Arzhan-2: reconstruction of the stages of functioning of the funeral-memorial complex and some questions of its chronology]. Rossiyskiy arkheologicheskiy yezhegodnik [Russian archaeological yearbook]. Saint Petersburg: Izd-vo Sankt-Peterb. gos. un-ta Publ., 2011, no. 1, pp. 262-335. (in Russ.).

Chugunov K. V. [The Scythian time Bronze arrowheads of Tuva]. Mirovozzreniye. Arkheologiya. Ritual. Kul'tura [Worldview. Archaeology. Ritual. Culture]. Saint Petersburg: Izd-vo SPb un-ta Publ., 2000, pp. 215-234. (in Russ.). Chugunov K. V. [Discreteness of the construction of "royal" memorials in Tuva and the chronology of the early Scythian time]. "Terra Scythica". Materialy mezhdunarodnogo simpoziuma "Terra Scythica" ["Terra Scythica". Materials of the international symposium "Terra Scythica"]. Novosibirsk: IAET SO RAN Publ., 2011, pp. 358-369. (in Russ.).

Chugunov K. V. [Classification of arrows by K. F. Smirnov and quiver sets of the Early Scythian time of the eastern zone as a chronological indicator]. Skifiya i Sarmatiya. K1oo-letiyu so dnya rozhdeniya K. F. Smirnova [Scythia and Sarmatia. To the $100^{\text {th }}$ anniversary of the birth of K. F. Smirnov]. Moscow: IA RAN Publ., 2019, pp. 31-44. (in Russ.). Chugunov K. V., Parzinger G., Nagler A. Tsarskiy kurgan skifskogo vremeni Arzhan-2 $v$ Tuve [The royal mound of the Scythian time Arzhan-2 in Tuva]. Novosibirsk: IAET SO RAN Publ., 2017. (in Russ.).

Dabney J., Knapp M., Glocke I. et al. Complete mitochondrial genome sequence of a Middle Pleistocene cave bear reconstructed from ultrashort DNA fragments. Proceedings of the National Academy of Sciences, 2013, vol. 110, iss. 39, pp. 15758-15763. DOI: 10.1073/pnas.1314445110 (in English).

Etnicheskaya odontologiya SSSR [Ethnic odontology of the USSR]. Moscow; Leningrad: Nauka Publ., 1979. (in Russ.).

Gindhardt P. Growth standards for the tibia and radius in children aged one month through eighteen years. American Journal of Physical Anthropology, 1973, vol. 39, iss. 1, pp. 41-48. (in English).

Goderhard E., Schellenberg H. M. [The bows of the Scythian time]. Chugunov K. V., Parzinger G., Nagler A. Tsarskiy kurgan skifskogo vremeni Arzhan-2 $v$ Tuve [Chugunov K. V., Parzinger G., Nagler A. The royal mound of the Scythian time Arzhan-2 in Tuva]. Novosibirsk: IAET SO RAN Publ., 2017, pp. 220-232. (in Russ.). 
Grach A. D. [New data on the ancient history of Tuva]. Uchenyye zapiski Tuvinskogo Nauchno-issledovatel'skogo instituta yazyka, literatury $i$ istorii [Proceedings of the Tuva Scientific Research Institute of Language, Literature and History]. Kyzyl: Tuv. kn. izd-vo Publ., 1971, iss. 15, pp. 93-106. (in Russ.).

Juras A., Chyleński M., Krenz-Niedbała M. et al. Investigating kinship of Neolithic post-LBK human remains from Krusza Zamkowa, Poland using ancient DNA. Forensic Science International: Genetics, 2017, vol. 26, pp. 30-39. DOI: 10.1016/j.fsigen.2016.10.008 (in English).

Kilunovskaya M. E., Semenov Vl. A., Busova V. S. et al. [The unique burial of a child of early Scythian time at the cemetery of Saryg-Bulun (Tuva)]. Stratum plus. Arkheologiya i kul'turnaya antropologiya [Stratum Plus. Archaeology and Cultural Anthropology], 2020, no. 3, pp. 379-406. (in Russ.).

Kustova Yu. G. Rebenok i detstvo v traditsionnoy kul'ture khakasov [Child and childhood in the traditional culture of the Khakass]. Saint Petersburg: "Peterburgskoye Vostokovedeniye" Publ., 2000. (in Russ.).

Liversidge H. M., Herdeg B., Rosing F. W. Dental estimation in non-adults. A review of methods and principles. Dental Anthroplogy, Fundamentals, Limits and Prospects. Vienna: Springer, 1998, pp. 419-422. (in English).

Maresh M. M. Measurements from roentgenograms. Human growth and development. Springfield, IL: C. C. Thomas, 1970, pp. 157-200. (in English).

Marsadolov L. S. [Salbyk's cultural and chronological stage in the history of ancient Khakassia]. Teoriya i praktika arkheologicheskikh issledovaniy [Theory and Practice of Archaeological Research], 2015, vol. 11, no. 1, pp. 7-31. DOI: 10.14258/tpai(2015)1(11).-O1 (in Russ.).

Mary L., Zvenigorosky V., Kovalev A. et al. Genetic kinship and admixture in Iron Age Scytho-Siberians. Human Genetics, 2019, vol. 138 (4), pp. 411-423. DOI: 10.1007/s00439-019-02002-y (in English).

Mathieson I., Lazaridis I., Rohland N. et al. Genome-wide patterns of selection in 230 ancient Eurasians. Nature, 2015, vol. 528, iss. 7583, pp. 499-503. DOI: 10.1038/nature16152 (in English).

Mednikova M. B. Bioarkheologiya detstva v kontekste rannezemledel'cheskikh kul'tur Balkan, Kavkaza i Blizhnego Vostoka [Bioarchaeology of childhood in the context of early agricultural cultures of the Balkans, the Caucasus and the Middle East]. Moscow: Club Print Publ., 2017. (in Russ.).

Mednikova M. B., Engovatova A. V., Tarasova A. A. [Diachronic changes in life-quality of the population of Yaroslavl in the $13^{\text {th }}-17^{\text {th }}$ centuries based on radiological data]. Rossiyskaya arkheologiya [Russian Archaeology], 2015, no. 3, pp. 94-106. (in Russ.).

Molodin V. I., Parzinger G., Tseveendorzh D. Zamorzshiye pogrebal'nyye kompleksy pazyrykskoy kul'tury na yuzhnykh sklonakh Saylyugema (Mongol'skiy Altay) [Frozen burial complexes of the Pazyryk culture on the Saylyugem southern slopes (Mongolian Altai)]. Moscow: "Triumf print” Publ., 2012. (in Russ.).

Murphy E. M., Schulting R., Beer N. et al. Iron Age pastoral nomadism and agriculture in the eastern Eurasian steppe: implications from dental palaeopathology and stable carbon and nitrogen isotopes. Journal of Archaeological Science, 2013, vol. 40, iss. 5, pp. 2547-2560. DOI: 10.1016/j.jas.2012.09.038 (in English).

Potrakhov N. N., Gryaznov A. Yu., Zhamova K. K., Bessonov V. B., Potrakhov Yu. N. [Microfocus X-ray: research results of the St. Petersburg State Electrotechnical University "LETI" named after V. I. Ulyanov (Lenin)]. Territoriya NDT [Territory NDT], 2016, no. 3, pp. 54-57. (in Russ.).

Rudenko S. I. Kul'tura naseleniya Tsentral'nogo Altaya $v$ skifskoye vremya [Culture of the Central Altai population in the Scythian time]. Moscow; Leningrad: AN SSSR Publ., 1960. (in Russ.).

Savinov D. G. Ranniye kochevniki Verkhnego Yeniseya. Arkheologicheskiye kul'tury i kul'turogenez [Early nomads of the Upper Yenisei. Archaeological cultures and cultural genesis]. Saint Petersburg: Izd-vo SPb un-ta Publ., 2002. (in Russ.).

Semenov Vl. A., Kilunovskaya M. E. [New sites of the early Iron Age in Tuva]. Informatsionnyy byulleten' Mezhdunarodnoy assotsiatsii po izucheniyu kul'tur Tsentral'noy Azii [Information Bulletin of the International Association for the Study of the Cultures of Central Asia]. Moscow: Nauka Publ., 1990, iss. 17, pp. 36-47. (in Russ.).

Staroverov N. E. Gryaznov A. Yu., Potrakhov N. N., Kholopova E. D., Guk K. K. New Methods for Digital Processing of Microfocus X-Ray Images. Biomedical Engineering, 2019, vol. 52, no. 6, pp. 435-438. DOI: 10.1007/s10527019-09864-6 (in English).

Sunduy G. V. Mir detstva kochevoy Azii: opyt dukhovno-nravstvennogo vospitaniya [The childhood world of nomadic Asia: the experience of spiritual and moral education]. Kyzyl: In-t razvitiya nats. shk.; Tuvinskoye kn. izd-vo Publ., 2009. (in Russ.).

Ubelaker D. H. Human skeletal remains: excavation, analysis, interpretation. Washington, D.C.: Taraxacum, 1989. (in English).

Vadetskaya E. B. Arkheologicheskiye pamyatniki $v$ stepyakh srednego Yeniseya [Archaeological sites in the steppes of the middle Yenisei]. Leningrad: Nauka Publ., 1986. (in Russ.).

Viktorova L. L. [The system of socialization of children and adolescents among the Mongols, the ways and reasons for the transformation of its elements]. Etnografiya detstva. Traditsionnyye formy vospitaniya detey i podrostkov u narodov Vostochnoy i Yugo-Vostochnoy Azii [Ethnography of childhood. Traditional forms of upbringing of children and adolescents among the peoples of East and Southeast Asia]. Moscow: Vostochnaya literatura Publ., 1983, pp. 51-72. (in Russ.). 